Mamoy Ibrahim ogly Mansurov,

$\mathrm{PhD}$ (Geology and Mineralogy), Associate Professor,

Department of Minerals, Faculty of Geology,

Baku State University, 23 Z. Khalilov St., Baku, AZ1148, Azerbaijan,

e-mail: mmansurov@bsu.edu.az, https://orcid.org/0000-0001-8673-3034

\title{
DISTRIBUTION PECULIARITIES OF BASIC ORE COMPONENTS IN GOSHGARCHAY PORPHYROUS COPPER DEPOSIT (LESSER CAUCASUS, AZERBAIJAN)
}

Мамой Ібрахім огли Мансуров. ОСОБЛИВОСТІ РОЗПОДІЛУ ГОЛОВНИХ РУДНИХ КОМПОНЕНТІВ КОШКАРЧАЙСКОГО МІДНО-ПОРФІРОВОГО РОДОВИЩА (МАЛИЙ КАВКАЗ, АЗЕРБАЙДЖАН). У статті вивчалися особливості розподілу головних рудних компонентів. При проведенні роботи по визначенню хімічних елементів, аналітичні дані оброблені методами математичної статистики. За вибіркою елементів були обчислені кореляційна матриця, факторні навантаження, власні значення і ваги факторів. Встановлено, щцо значення фактора Ф1 корелюють з кількістю халькопіриту, борніту і піриту, щчо дає підставу пов'язати геохімічну асоціачџю $\mathrm{Cu}(\mathrm{Mo}, \mathrm{Pb}, \mathrm{Sb})$ с найбільш ранньою халькопіритборніт-піритовою мінералізацією порфірового етапу формування рудоносної структури. Значення фактора Ф2, що відповідають асоиіації Мо (Cu, Pb, Со), статистично пов'язані з утриманням халькопіриту і молібденіту, щчо утворюють основний мінеральний парагенезис мідь-молібден-порфірового зруденіння. За результатами факторного аналізу даних свердловин виявлені геохімічні асочіачії, що дозволяють локалізувати області розвитку мінералізачії різних стадій формування порфірово-епітермальної системи. Для з'ясування повної статистичної характеристики геохімії рудних компонентів родовища будували точкові діаграми залежності. 3 аналізів діаграм точкової залежності між вмістами рудних елементів можна прийти до висновку, шо переважна більшість вивчених хімічних елементів пов'язана позитивним корелячійний зв'язком. Виявлено, шо кореляція між елементами мідно-порфірового зруденіння характеризується широким діапазоном елементних домішок. Сюди входять як халькофільні (As, Sb, Cu, Bi, Cd, Ga, In, Ge, $\mathrm{Au}, \mathrm{Ag}, \mathrm{Te})$, так і сідерофільні (Co, $\mathrm{Ni}, \mathrm{Mo}, \mathrm{Fe}$, Cr) елементи. Наведені дані дозволяють говорити про різні умови міграції та конщентрації молібдену $і$ міді в головних рудоутворюючих прочесах.

Ключові слова: Кочкарчай, мідно-порфірове зруденіння, структурно-морфологічні особливості, мінеральний склад, геохімічні особливості, рудні компоненти, факторний аналіз, точкова залежність, кореляиійний зв'язок.

Мамой Ибрагим оглы Мансуров. ОСОБЕННОСТИ РАСПРЕДЕЛЕНИЯ ГЛАВНЫХ РУДНЫХ КОМПОНЕНТОВ КОШКАРЧАЙСКОГО МЕДНО-ПОРФИРОВОГО МЕСТОРОЖДЕНИЯ (МАЛЫЙ КАВКАЗ, АЗЕРБАЙДЖАН). В статЬе изучались особенности распределения главных рудных компонентов. При проведении работы по определению химических элементов, аналитические данные обработаны методами математической статистики. По выбороке элементов были вычислены корреляционная матрица, факторные нагрузки, собственные значения и веса факторов. Установлено, что значения фактора Ф1 коррелируют с количеством халькопирита, борнита и пирита, что дает основание связать геохимическую ассоииачию $\mathrm{Cu}(\mathrm{Mo}, \mathrm{Pb}, \mathrm{Sb})$ с наиболее ранней халькопирит-борнит-пиритовой минерализацией порфирового этапа формирования рудоносной структуры. Значения фактора Ф2, отвечающие ассоциации Мо (Си, Рb, Со), статистически связаны с содержанием халькопирита и молибденита, образующих основной минеральный парагенезис медь-молибденпорфирового оруденения. По результатам факторного анализа данных скважин выявлены геохимические ассочиации, позволяющие локализовать области развития минерализации различных стадий формирования порфирово-эпитермальной системы. Для выяснения полной статистической характеристики геохимии рудных компонентов месторождения строили точечные диаграммы зависимости. Из анализов диаграммы точечной зависимости между содержаниями рудных элементов можно прийти к выводу, что подавляющее большинство изученных химических элементов связано положительной корреляционный связью. Выявлено, что корреляция между элементами медно-порфирового оруденения характеризуется широким диапазоном элементных примесей. Сюда входят как халькофильные ( $A s, S b, C u, B i, C d, G a, I n, G e, A u, A g, T e), m a \kappa$ и сидерофильные (Co, $\mathrm{Ni}, \mathrm{Mo}, \mathrm{Fe}, \mathrm{Cr}$ ) элементы. Приведенные данные позволяют говорить о различных условиях миграции и конщентрачии молибдена и меди в главных рудообразующих проиессах.

Ключевые слова: Кошкарчай, медно-порфировое оруденение, структурно-морфологические особенности, минеральный состав, геохимические особенности, рудные компоненты, факторный анализ, точечная зависимость, корреляционая связь.

Scientific novelty and practical importance. To solve the problem, the author studied behavior of chemical elements in ore-bearing rocks and mineral associations, building a series of dependency dot plots, showing dependency relationships between the elements. As one can see from the analysis, the scatter plots of dependence repeat in pairs symmetrically about the diagonal. In order to study the characteristics of the indicator elements, the author clarified relationships between them and statistically analyzed geochemical properties of the field. The obtained geochemical information on the main ore components in porphyry copper ores and ore-hosting rocks can be used in the improved technological scheme for ore processing. The scheme is aimed at a complete complex extraction of the main and accompanying elements, copper and molybdenum, other valuable components of the studied deposits.

Introduction. Porphyry copper deposits are among the main sources of $\mathrm{Cu}, \mathrm{Mo}, \mathrm{Au}, \mathrm{Ag}$, Sn with accompanying Re, W, In, Pt, Pd, and Se. They account for 50 to $60 \%$ of world copper production and more than $95 \%$ of world Mo production. Numerous studies of porphyry copper deposits are aimed primarily at identifying the features of their formation 
in different geodynamic settings, creating descriptive and genetic models as the basis for effective forecasting, prospecting and assessment of territories with economically important mineral deposits [1-8].

The problem of forecasting, studying and evaluating copper-molybdenum-porphyry deposits in the volcanogenic belts of the Azerbaijani part of the Lesser Caucasus is one of the most urgent. It is extremely important for solving the issue of expanding the mineral resource base not only of copper and molybdenum, but also gold and silver, platinum group elements, poly-metals, rare and rare- earth elements. In the Lesser Caucasus, copper deposits and ore occurrences are widespread in all metallogenic zones. They belong to three genetic types of industrial importance: copper-porphyry, copperpyrite, and copper-polymetallic. All of them are associated with volcano-intrusive and plutonic complexes of the Lesser Caucasus [2]. Porphyry copper mineralization associated with plutonic granitoid massifs of the Murovdag ore region is the most promising. There are also several deposits and ore occurrences of copper-porphyry type, in which copper ores can be classified as large deposits. The Goshgarchay deposit is the most well- studied and explored, and this makes it a very promising one. Thus, using the example of this deposit, we consider the distribution features of the main ore components of this ore region.

Analysis of previous studies. Large sizes and large reserves, as well as the possibility of using rational methods of metal extraction predetermined an increased interest in porphyry copper deposits, which are currently the main raw material base for $\mathrm{Cu}$, Mo. Deposits often contain a number of associated components in industrial quantities among which $\mathrm{Au}, \mathrm{Ag}, \mathrm{Bi}, \mathrm{Te}, \mathrm{Re}$ and Se play a leading role. Their accounting significantly increases the total value of ores [2, 4-8]. They are accompanied by numerous polymetallic, gold-silver, pyrite satellite deposits and placers. The study of porphyry copper mineralization of the Murovdag ore region began during the period of intensive exploration of porphyry deposits in the Lesser Caucasus $[1,2,23]$. Endogenous deposits of the Lesser Caucasus are represented by a wide range of genetic and formational types. At present, there is sufficiently substantiated opinion that these deposits form a complex polygenic group with pronounced features of polycyclic development, a variety of tectonic conditions and forms of magmatism manifestations. [2, 4, 5, 7].

A significant amount of the research as well as their wide geography is devoted to the problems of endogenous ore deposits of the Murovdag ore region. Deposits of different age and different formations of various ores are concentrated there.
The features of these deposits are highlighted in monographic summaries, numerous publications [1$3,12,13,23]$, such as monographs by Baba-zade and others [1], Baba-zade and others [2]. They include articles on geology, mineralogy, geochemistry, formation parameters, isotopic studies of objects of the Goshgarchay ore field $[3,12,13]$. In the work on the Porphyry Copper Formation of Azerbaijan, V.G. Ramazanov touched upon a number of geological and geochemical features of the Goshgarchay porphyry copper deposit, its connection with magmatism and other issues. Later, we conducted research in this area and published a number of articles in various journals $[2,12,13,15]$. At the same time, studies devoted to the compilation of geological-genetic models of porphyry copper and polymetallic deposits were incomplete. This is explained by their rather large diversity, the idea of their formational affiliation, connection with magmatism and peculiarities of ore components and impurity elements distribution $[2,4,10]$. The results, presented in the works, indicate the exceptional relevance of this issue. When processing the materials, the author used both classical literature $[1,2,9,11$, $23]$ and modern publications $[3,12,13,15,19]$. The distribution features of the main ore components in the host rocks and ores of the Goshgarchay deposit have not been sufficiently studied in these works.

The value of porphyry copper deposits primarily lies in the fact that they have been discovered in geologically well-studied areas. The ores, with a relatively low content of the main $(\mathrm{Cu}, \mathrm{Mo})$ and associated components ( $\mathrm{Au}, \mathrm{Ag}, \mathrm{Bi}, \mathrm{Re}, \mathrm{Se}, \mathrm{Te})$, in them, are characterized by more areal distribution and significant reserves. These features of porphyry copper deposits make them potentially promising. Therefore, a comprehensive geological study of them, including the distribution features of the main ore components of the Goshgarchay deposit, is very relevant. Our goal here was to study these distribution features of ore-generating components by means of mathematical - statistical calculation of analytical data. The obtained e results can form the basis for geochemical criteria for direct prospecting and forecasting of hidden porphyry copper ores.

Subject and object of the research. The subject of this research is the study of distribution regularities of ore and nonmetallic components in ores; the object is geochemical features of trace elements distribution and behavior of chemical elements of ores during the Goshgarchay deposit formation.

Features of the geological structure of the field. Features of the geological structure of the Goshgarchay porphyry copper deposit are detailed in previously published works $[1-3,9]$. The Murovdag ore region, which includes the Goshgarchay deposit, being an integral part of the Lok- 
Karabakh island arc [9] (Fig. 1), occupies the NW uplifted part of the Murovdag anticlinorium of asymmetric structure, composed of rocks of the Lower Bayossky volcanogenic strata in the core and the Upper Bathyesian Basalite and -ryolite sequentially differentiated formation on the wings [10]. The intrusive components of the ore region are the Goshgarchay complex of granitoid intrusions Goshgardag, Ojagdag, Baladzha Goshgardag) and their dike formations, which break through a powerful complex of effusive-pyroclastic formations, exerting a contact effect on them. Geological and petrological features of intrusive complexes with porphyry copper mineralization belong to the Late JurassicEarly Cretaceous gabbro-diorite-granodiorite formation $[9,11]$.

In the ore region, porphyry copper mineralization encompasses the Goshgarchay, Goshgardag, Kyzylarkhach, Kechaldag, Erik-Manuks and other deposits and ore occurrences, where it is in close spatial and genetic connection with the Murovdag granitoid massifs $[2,10]$. According to their geological position and spatial distribution, the intrusive formations of the Murovdag group are divided into the Goshgardag and Kyzylarkhach groups [11].

Intrusive formations are represented mainly by quartz diorite, gabbro-diorite and slightly diorite, gabbro, banatite. When approaching the endocontact, the rocks acquire a more basic character. Gabbronorites are medium-grained almost black rocks, consisting of plagioclase, pyroxenes, small amounts of biotite, hornblende, olivine, as well as secondary and accessory minerals. Quartz diorites are finemedium-grained, full-crystalline rocks, represented mainly by plagioclases, hornblende, biotite, quartz, sometimes with an admixture of pyroxene, potassium feldspar, and albite $[2,11]$.

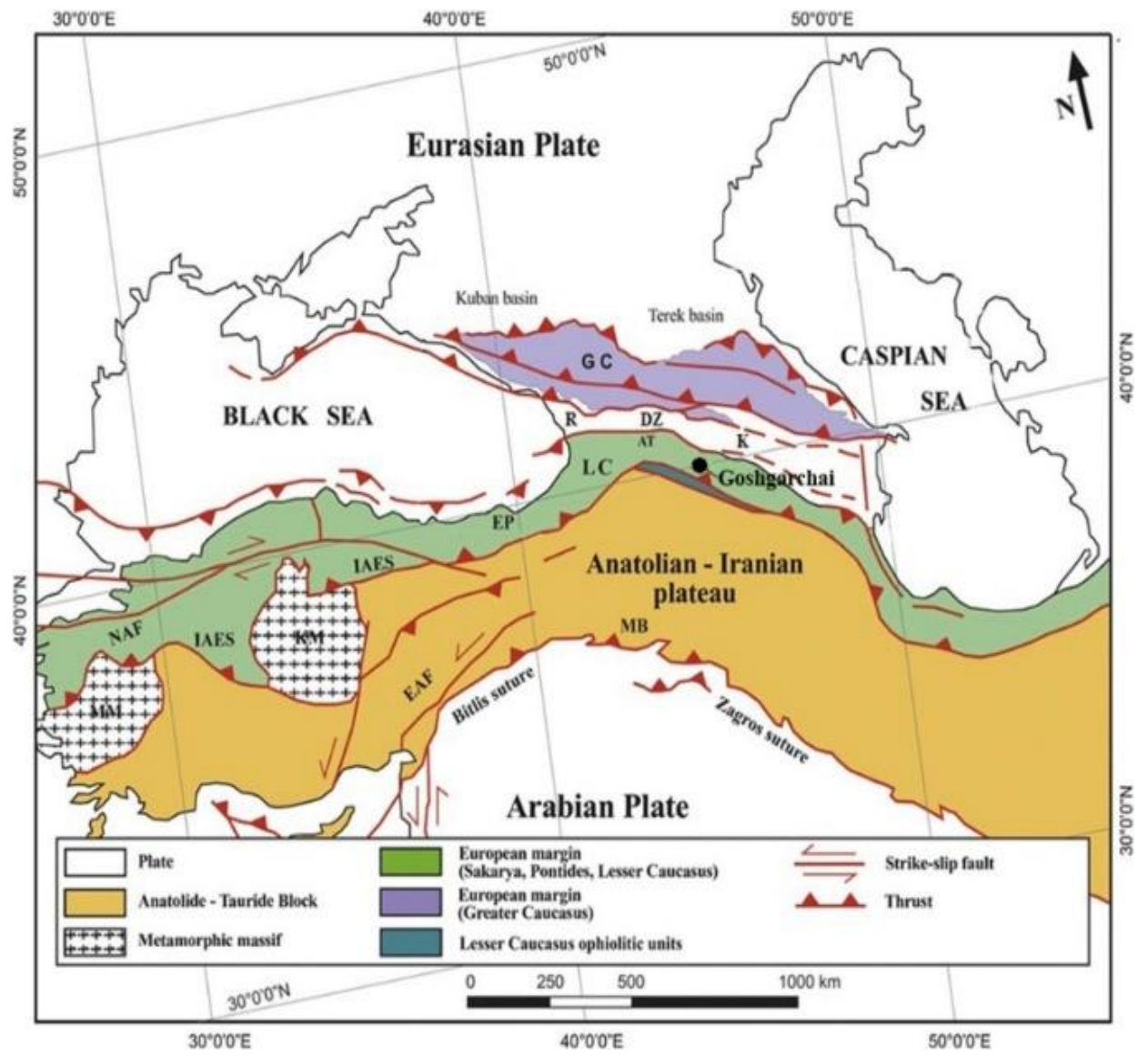

Fig. 1. Tectonic map of the Arabian-Eurasian collision zones. The location of the Goshgarchay deposit is shown by a circle. (Sosson et al., 2010). Abbreviations: GC-Greater Caucasus; LC-Lesser Caucasus; AT-Achara-Trialeti; R-Rioni; Dz-Jirula; K-Kura; MB - Mus Basin; EP - Eastern Pontids; KM - Kirsehir massif; EAF - Eastern Anatolian Fault; NAF - North Anatolian Fault; IAES-Izmir-Ankara-Erzincan seam; MM- Menderes Massif

The spatial distribution of porphyry copper mineralization is controlled by faults of various directions, which determine the block structure of the ore region [3]. Many of them are accompanied by hydrothermal alteration of rocks: silicification, se- ricitization, chloritization, and epidotization. Hydrothermal-metasomatic alterations are also developed along the contacts of intrusive rocks, selvages, dikes and veins. The original rocks transformed into metasomatites are both intrusive and host volcanic for- 
mations [13, 14]. Metasomatites and host igneous rocks of the studied deposits have similar distribution parameters, which may indicate that similar igneous rocks have become a substrate for metasomatism [15].

Structural and morphological features and mineral composition of the deposit. The deposit is dominated by vein-disseminated stockwork ores. The vein type of mineralization is of subordinate importance and is confined to zones of crushing and zones of hydrothermal alteration among diabase porphyrites. The named type of mineralization is represented by quartz and carbonate veins and veins impregnated with pyrite, chalcopyrite and molybdenite $[1,2]$.

The stockwork body, occupying the central part of the Goshgarchay deposit, is confined to the apical and peripheral parts of the intrusion of the same name, more precisely, to its endo- and exo-contact strip and in the sub-latitudinal direction occupies an area of about $0.8 \mathrm{~km} 2$.

Copper content of $0.4 \%$ and 10 ore pillars were identified within the stockwork on the surface. Interpretation of the analysis results of core materials allows us to consider these enriched areas as merging at depth into a single ore body, forming a stockwork with a complex morphology. The surface of the stockwork body is especially complex. In the stockwork, cracks of the northwestern (280-3200), submeridional (345-100) and sublatitudinal directions are developed, filled with no ore and quartzsulfide matter [2, 12]. The veins, represented by quartz-carbonate fillers, have sub-latitudinal spread. They are confined to crushing zones with a thickness of 30-60 $\mathrm{m}$ among diabase porphyrites.

The main useful component is copper. Its content within the stockwork body is unstable and fluctuates in a wide range - from 0.2 to $2.5 \%$, averaging $0.41 \%$. Molybdenum and precious metals should be noted among a number of ore minerals that significantly affect the importance of the deposit. In some intervals, the average gold grade is $2.0 \mathrm{~g} / \mathrm{t}$ and more. Along with gold, an increased silver content has also been established, its value reaching 30-45 g/t, which can positively affect the overall value of the deposit.

We can say that based on the structural and morphological features, mineralization of the Goshgarchay deposit is a stockwork-vein disseminated type, in which dissemination prevails over veinlets and veins.

In deposits, mineral composition of ores is not very diverse and is characterized mainly by the small size of ore minerals, their close intergrowths. As a result of the study of polished sections in ores, the author identified the following ore minerals: pyrite, chalcopyrite, sphalerite, arsenopyrite, melni- kovite - pyrite, marcasite-pyrite, marcasite, fahlore, cobalt-pyrite, enargite, galena, cobaltin, molybdenite, bismuthin, boronite ilmenite, hematite, chrome spinelite, chalcocite, covellite, malachite, azurite, limonite, etc. Of these, the main ore minerals of the deposit are chalcopyrite, bornite, pyrite, molybdenite, tenantite, chalcosine, enargite, native copper, gold and rutile. Vein minerals are represented by quartz, calcite, epidote, kaolinite, sericite, chlorite, biotite, muscovite, etc. [2,3].

The purpose and objectives of the research. The aim of the research is to study the distribution features of the main ore components in the Goshgarchay porphyry copper deposit. To achieve the set goal of the study, the author considered statistical distribution of chemical elements content in ores and host rocks as well as the possibility of using them as geochemical indicators for the detection of hidden ore bodies.

Materials and research methods. The basis for the factual material was a collection of samples (about 150 pieces) taken inside and around the stockwork with vein-disseminated mineralization and on its flank to a depth of more than $500 \mathrm{~m}$ from the surface. Data from geochemical sampling of orehosting rocks and ores in mine workings and core samples from boreholes were used for this along sections directed perpendicular to the strike of oreconcentrating structures. The collection includes samples taken from gabbroids, quartz diorites, quartz veins with galena-sphalerite-chalcopyrite mineralization. Atomic absorption analysis on a Perkin Elmer device allowed to quantitatively determine such elements as $\mathrm{Cu}, \mathrm{Mo}, \mathrm{Au}, \mathrm{Ag}, \mathrm{Se}, \mathrm{Te}$, $\mathrm{Cr}, \mathrm{Ni}, \mathrm{Co}, \mathrm{Pb}, \mathrm{Zn}, \mathrm{Sr}, \mathrm{Cd}, \mathrm{As}, \mathrm{Bi}$. The geochemical data for the wells were processed in the STATISTIKA program, using the factor analysis of the main components. Methods of semi-quantitative spectral analysis were applied to study the contents of chemical elements in the host rocks and porphyry copper ores. The main ore samples were taken from the vein-disseminated stockwork type ores. The rock samples were examined by inductively coupled plasma mass spectroscopy (ISP-MS). Silicate chemical analysis was carried out in the laboratory of Izmir University, Turkey. The rock samples were examined by inductively coupled plasma mass spectroscopy (ISP-MS). Analytical studies were performed at the USGS Analytical Laboratory of the United States Geological Survey (Denver).

Results of the research. Geochemical features of ore-forming systems. The study of geochemical features of the porphyry copper systems in the Murovdag ore region was based on the results of the chemical analysis of core samples from wells at a depth of up to $280 \mathrm{~m}$ on average. The geochemical data for the wells were processed in the STATICTI- 
KA program by the method of factor analysis of the main components [16,17]. Chemical elements in the ores of the Goshgarchay deposit were studied, using different analytical methods. Semi-quantitative analysis studied the content of 14 chemical elements, focusing on the geochemistry of the deposit ores itself. To study peculiarities of the main ore components distribution, the author used the methods of factor analysis and the matrix of graphs, reflecting the correlations between the ore elements. As a result of the processing, we obtained three factors, reflecting the correlations between the fourteen ore elements.

According to the weights, the elements are grouped into factors or geochemical associations that can be compared with the mineral parageneses of the main stages of ore deposition $[8,16]$. The cor- relation of geochemical and mineral associations is confirmed by the correlation coefficients between the factor analysis of elements and the sulfide content according to the data from well core sampling.

The F1 values correlate with the amount of chalcopyrite, bornite, and pyrite, which gives grounds to associate the geochemical association of $\mathrm{Cu}(\mathrm{Mo}, \mathrm{Pb}, \mathrm{Sb})$ with the earliest chalcopyritebornite-pyrite mineralization of the porphyry stage of the ore-bearing structure formation. The F2 values, corresponding to the $\mathrm{Mo}(\mathrm{Cu}, \mathrm{Pb}, \mathrm{Co})$ associations, are statistically related to the content of chalcopyrite and molybdenite, which form the main mineral paragenesis of copper-molybdenumporphyry mineralization $[8,16]$. The plots of dependence $F 1$ and F2 based on the results of factor analysis are shown in Figure 2.

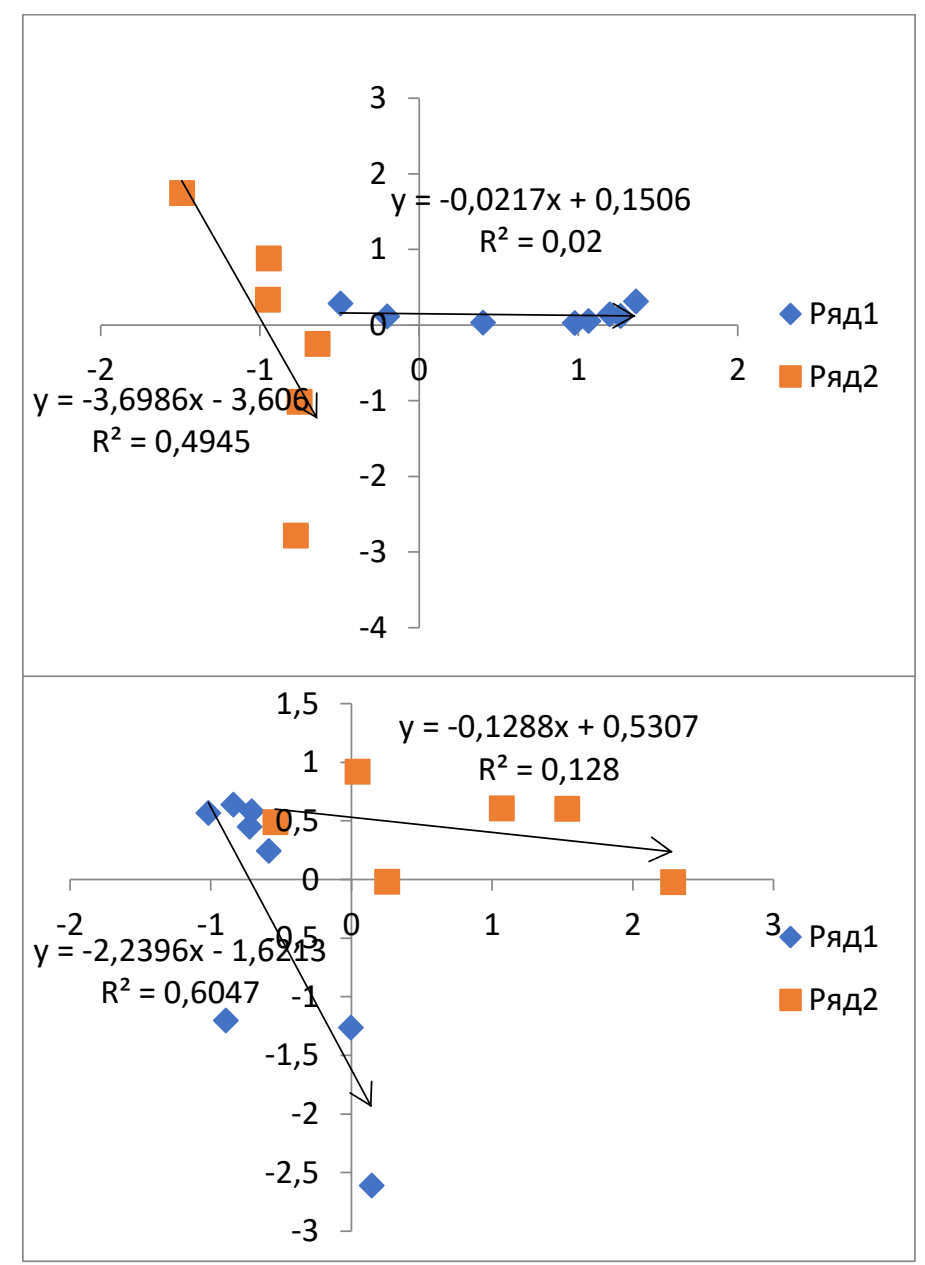

Fig. 2. Dependence of F1 and F2 based on the result of factor analysis

Based on the results of a factorial analysis of well testing data, the author has identified geochemical associations, which made it possible to localize the areas of mineralization development at various stages of the porphyry-epithermal system formation. The range of vertical geochemical zoning values for individual sections of the field makes it possible to assess the level of the erosional section in the porphyry-epithermal system $[8,17]$.

To clarify the complete statistical characteristics of the geochemistry of the ore components in the deposit, we built point dependence diagrams. Scatter plots of the dependence are repeated in pairs symmetrically about the diagonal. The vertical axis 
is the dependent variable, the horizontal axis is independent. Figures 3 and 4 show well-correlated variables. Close correlation between $\mathrm{Cu}$ and $\mathrm{Ag}, \mathrm{As}$, $\mathrm{Bi}, \mathrm{Cd}, \mathrm{Ce}, \mathrm{Co}, \mathrm{Cr}, \mathrm{Cs}, \mathrm{La}, \mathrm{Li}, \mathrm{Mo}$ is much more interesting. Here the scatter of points near the regression line is larger and the correlation coefficient is rather high $(\mathrm{r}=0.73)$. The analysis of scatter diagrams shows that all the elements of this graph are interconnected by a direct positive relationship [18]. In this diagram, three point clouds are highlighted and the largest compact point cloud corresponds to the primary sulphide ores of the deposit. Two more clouds with a small number of points are characterized by anomalous contents of ore-forming elements. The clouds of these points with anomalous contents correspond to the oxide ores of the deposit.
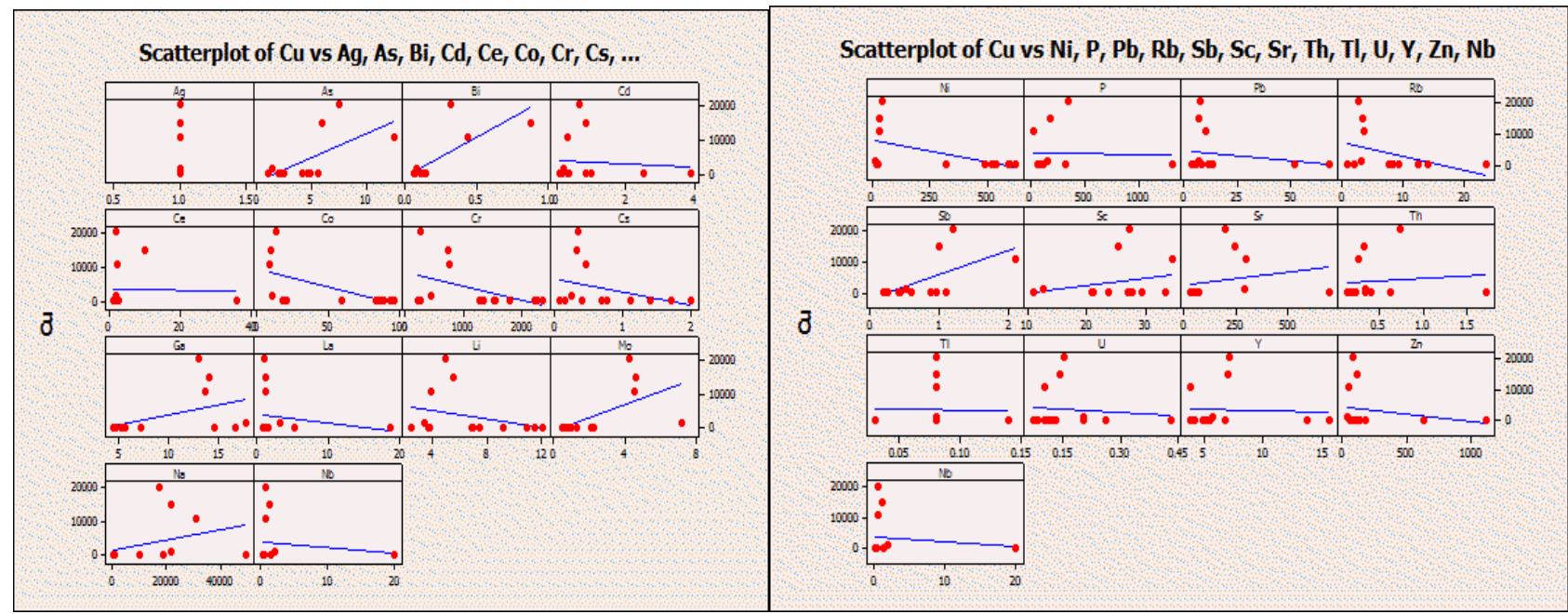

Fig 3. Diagram of the point relationship between $\mathrm{Cu}$ contents and other basic ore elements

Fig. 4 shows dot diagrams of the relationship between Mo contents with other elements $(\mathrm{Pb}, \mathrm{Sb}$, $\mathrm{Cu}, \mathrm{Rb}, \mathrm{P}, \mathrm{Se}, \mathrm{Sr}, \mathrm{Th}, \mathrm{Ti}, \mathrm{Zn}, \mathrm{Ni}, \mathrm{V}, \mathrm{Cr}$, etc.).

These diagrams unambiguously show that the point cloud is stretched in a completely clear direction for individual elements, and the red straight line, which should follow exactly along the axis of this elongated cloud. In our diagram, copper in the Goshgarchay deposit in the upper part of the ore body has undergone dramatic enrichment due to oxidation and secondary sulfide enrichment processes. Large $\mathrm{Cu}$ contents as well as newly formed sulfides (chalcocite, bornite, covellite) and even native copper appeared because of this. This shows that our sample includes products of both the hypogenic and hypergene mineral formation stages $[5,7]$.

We can conclude from the analyses of the dia-

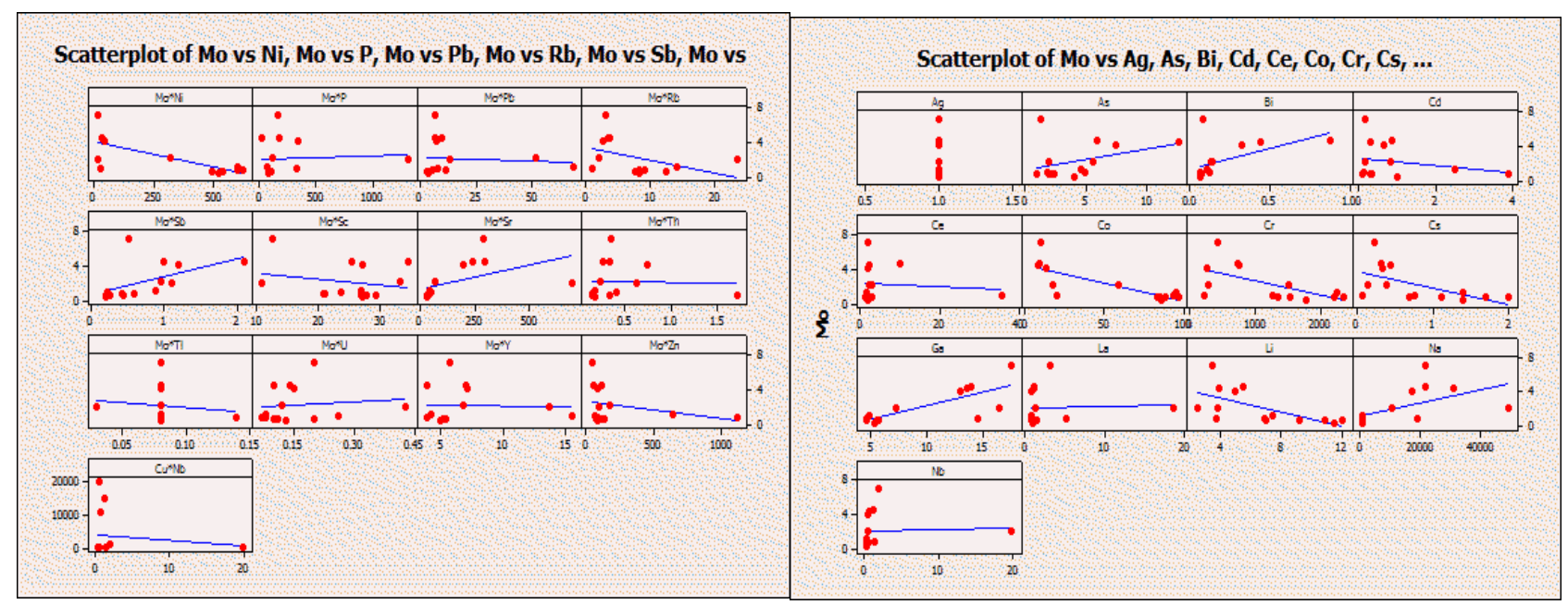

Fig.4. Diagram of the point relationship between Mo contents and other basic ore elements

gram of the point dependence between the contents of ore elements that the overwhelming majority of the studied chemical elements are associated with a positive correlation. As you can see, in the diagram of the connection of $\mathrm{Cu}$ and Mo with other components, the overwhelming majority of all point clouds are located along a straight line, and some are outside this line. This is normal in defining elements 
when high and low values of the elements do not deviate too much from the straight line. This shows that all the elements were formed in a single geochemical process.

As we see from the correlation between the elements, the porphyry copper mineralization is characterized by a wide range of elemental impurities. This includes both chalcophilous (As, $\mathrm{Sb}, \mathrm{Cu}, \mathrm{Bi}$, $\mathrm{Cd}, \mathrm{Ga}, \mathrm{In}, \mathrm{Ge}, \mathrm{Au}, \mathrm{Ag}, \mathrm{Te})$ and siderophilous (Co, $\mathrm{Ni}, \mathrm{Mo}, \mathrm{Fe}, \mathrm{Cr}$ ) elements. Determination of elemental impurities is not the same in different types of ores and mineral associations, their amount is thousand times higher than the clark amount and the concentration coefficient. Three different mineral associations coexist in the ore body: 1-primary sulfide-chalcopyrite and bornite-chalcopyrite ore; 2oxidized ore and secondary sulphide concentration zones; 3-primary sulfide ores, significantly enriched in copper [8].

One can find a similar picture in a number of deposits of the porphyry copper proper type in the Lesser Caucasus. That is, along the main ore zones, characterized by a good correlation of all ore elements, there are distinguished local essentially monometallic areas with high copper and molybdenum contents [4]. In large deposits, this corresponds to a frequent spatial discrepancy between zones of maximum concentration of copper, gold, silver and molybdenum, usually distributed in accordance with the typical ore-geochemical zoning (molybdenum-copper-base metals, silver upward and laterally) [5].

As follows from the analysis of the above results, elements that are of little character for hydrothermal solutions $(\mathrm{Cr}, \mathrm{Ni}, \mathrm{V}, \mathrm{Co}, \mathrm{Mn}, \mathrm{Ti})$ retain their independence in all rock groups. Presence of their groups is most likely associated with the process of crystallization differentiation of magma. Such elements as $\mathrm{Cu}, \mathrm{Pb}, \mathrm{Zn}, \mathrm{Ag}$ and, partly, $\mathrm{Mo}$, do not have their specific places. Therefore, their presence in one or another group is associated with the degree of rocks exposure to hydrothermal effects, which is the source of these elements $[19,20]$.
These data allow us to speak about different conditions of migration and concentration of molybdenum and copper in the main ore-forming processes. However, these do not exclude the possibility of finding copper in molybdenum-containing, and molybdenum in copper-containing mineralizing solutions. Elucidation of these conditions, along with the study of the solubility of molybdenum and copper natural sulphides, is important for clarifying the concepts of transport forms, as well as understanding the features of the redistribution and removal of molybdenum and copper when the late hydrothermal-metasomatic formations are superimposed on earlier ones [21, 22, 23$]$.

Conclusions. 1. From the point of view of structure and morphology, mineralization of the Goshgarchay deposit belongs to the stockwork-vein disseminated type, in which disseminations prevail over streaks and veins.

2. The values of F1 factor correlate with the amount of chalcopyrite, bornite and pyrite, and the values of F2 factor are statistically related to the content of chalcopyrite and molybdenite.

3. There is a close positive correlation between the chemical elements of mineralization, indicating the fact that they are the product of a single geochemical process.

4. Geochemically, the porphyry copper mineralization of the Goshgarchay deposit is characterized by a wide range of various elemental impurities, including both chalcophilous (As, $\mathrm{Sb}, \mathrm{Cu}, \mathrm{Bi}$, $\mathrm{Cd}, \mathrm{Ga}$, İn, $\mathrm{Ge}, \mathrm{Au}, \mathrm{Ag}, \mathrm{Te})$ and siderophilous $(\mathrm{Co}$, $\mathrm{Ni}, \mathrm{Mo}, \mathrm{Fe}, \mathrm{Cr}$ ) elements.

5. Ore mineralization contains three different mineral associations: 1-primary sulfide-chalcopyrite and bornite-chalcopyrite ore; 2-oxidized ore and secondary sulphide concentration zones; 3-primary sulphide ores, significantly enriched in copper.

6 . The revealed regularities in the distribution of $\mathrm{Cu}$ and Mo can become a direct geochemical criterion for prospecting for hidden porphyry copper ores in the region.

\section{Bibliography}

1. Минерально-сырьевые ресурсы Азербайджана (условия формирования, закономерности размещения, научные основы прогнозирования) [Текст] / ред. В.М. Баба-заде. - Баку: Озан. - 2005. - 808 с.

2. Баба-заде В.М.. Медно- и молибден-порфировые месторождения [Текст] / В.М. Баба-заде, А.И. Махмудов, В.Г. Рамазанов. - Баку: Азернешр. - 1990. -367c.

3. Мансуров М.И. Модели рудно-магматических систем медно-порфировых месторождений Гошгарчайского рудного поля (Малый Кавказ, Азербайджан) [Текст] / М.И. Мансуров // Известия Сибирского отделения Секции наук о Земле Российской академии естественных наук. Геология, поиски и разведка рудных месторождений, 2014. - 4 (47). - C. $29-42$.

4. Попов В.С. Геология и генезис медно-молибден-порфировых месторождений [Текст] / В.С. Попов. -Москва: Наука. $-1977 .-201 c$.

5. Титли С.Р. Медно-порфировые месторождения. Генезис рудных месторождений [Текст] / C.P. Титли, Р.Е. Бин. - Москва: Мир. - 1984. - 385c.

6. Волков А.В. Закономерности размещчения и условия образования Си-Аи-порфировых месторождений Северо- 
Востока России [Текст] / А.В. Волков, Н.Е. Савва, А.А. Сидиров // Геология рудных месторождения -2006. 48 (6), - C.512-539.

7. Sillitoe R.H. Porphyry Copper Systems, Society of Economic Geologists, Inc. [Text] / R.H. Sillitoe // Economic Geology, 2010. - Vol. 105. - P. 3 - 41 .

8. Николаев Ю.Н. Аи-Аg минерализация порфирово-эпитермальных систем Баимской зоны (Западная Чукотка, Россия) [Текст] / Ю.Н. Николаев, И.А. Бакшеев, В.Ю. Прокофьев, Е.В. Нагорная, Л.И. Марущенко, Ю.Н. Сидорина, А.Ф. Читалин, И.А. Калько // Геология рудных месторождения, 2016. -T. 58 (4). - С.319-345.

9. Геология Азербайджана. Тектоника [Текст] / ред. A. Али-заде. -Баку: Nafta-Press, -2005. - 565c.

10. Абдуллаев Р.Н. Мезозойские магматические формации Малого Кавказа и связанное с ними эндогенное оруденение [Текст] / Р.Н. Абдуллаев, Г.В. Мустафаев, М.А. Мустафаев. -Баку: Элм, 1998. -185c.

11. Геология Азербайджана, Магматизм [Текст] / ред. А.Али-заде. -Баку: Nafta-Press, 2003. - 505c.

12. Мансуров М.И. Геолого-генетическая модель Гошгарчайской рудно-магматической системы Муровдагского поднятия (Мальй Кавказ, Азербайджан) [Текст] / М.И. Мансуров // Известия Национальной академии наук Азербайджана, Науки о Земле, 2013. - №4. - С.16-22.

13. Мансуров М.И. Зональность оруденения и метасоматитов в медно-порфировых месторождениях Гошгарчайской рудно-магматической системы (Мальий Кавказ, Азербайджан) [Текст] / М.И. Мансуров, М.Г. Сафари, Б.Г. Каландаров, В.М. Керимов, А.Г. Мамедова // Известия Сибирского отделения секции наук о Земле Российский Академии Естественных Наук. Геология, разведка и разработка месторождений полезньх ископаемых, 2018. -T.41(1). - С. 38-53.

14. Марущенко Л.И. Квари-серицитовые метасоматиты и аргиллизиты Аи-Мо-Си месторождения Песчанка (Чукотка) [Текст] / Л.И. Марущенко, И.А. Бакшеев, Е.В. Нагорная, А.Ф. Читалин, Ю.Н. Николаев, И.А.Калько, В.Ю. Прокофьев // Геология рудных месторождения, 2015. -T. 57 (3). - С.239-252.

15.Имамвердиев Н.А. Редкоземельные элементы в магматических и метасоматических породах Муровдагского рудного района (Мальй Кавказ) [Текст] / Н.А. Имамвердиев, В.М. Баба-заде, М.И. Мансуров, Ш.Ф. Абдуллаева // Геохимия, 2020. - Т. 65, № 2. - С. 178-184.

16. Белонин М.Д. Факторный анализ в геологии. [Текст] / М.Д. Белонин, В.А. Голубева, Г.Т. Скублов. -Москва: Недра, 1982. $-265 c$.

17. Боровиков В.П. Популярное введение в современный анализ данных в системе STATISTICA. Учебное пособие для для вузов. [Текст] /В.П. Боровиков Москва: Горячия линия-Телеком, 2013. - 156с.

18. Грабежев А.И., Чащухина В.А. О корреляциии между элементами медно-порфировых месторождений [Текст] / А.И. Грабежев, В.А. Чашухина // Геохимия, - Москва, 1985. - № 12. - С. 1792-1794.

19. Баба-заде В.М. Минералого-геохимические факторы золотоносности руд медно-порфировых месторождений Ордубадского рудного района [Текст] / В.М. Баба-заде, В.Г. Рамазанов, Н.А. Аббасов // Вестник Бакинского Университета. Серия естественных наук. - Баку, 2015. - №3. - C.122-129.

20. Наумов Н.Б. Кониентрация рудных элементов в магматических расплавах и природных флюидах по даннылм изучения включений в минералах [Текст] / Н.Б. Наумов, А.В. Гирнис, В.А. Дорофеева, В.А. Коваленкер // Геология рудных месторождения, 2016. - Т. 58 (4). - С. 367-384.

21. Геохимия процессов миграций рудных элементов [Текст] / Ред. Н.И. Хитаров. -Москва: Наука, - 1977. $270 \mathrm{c}$.

22. Керимли У. (2020). Стадии минерализаџии и факторы локализации Агюртского золото-медномолибденового месторождения (Мальй Кавказ, Азербайджан) [Текст] / У. Керимли // Вестник Киевского национального университета имена Тараса Шевченко, 2020. - № $2 . \quad$ - C. 96-101. https://doi.org/10.17721/1728-2713.69.13

23. Рамазанов В.Г. Медно-порфировая формация Азербайджана [Текст] / В.Г. Рамазанов-Баку: Элм, 1993. $45 \mathrm{c.}$

Submitted February 26, 2021

Accepted April 28, 2021

UDC 553.3/.4.078

Mamoy Mansurov,

$\mathrm{PhD}$ (Geology and Mineralogy), Associate Professor,

Department of Minerals, Faculty of Geology,

Baku State University, 23 Z. Khalilov St., Baku, AZ1148, Azerbaijan,

e-mail: mmansurov@,bsu.edu.az, https://orcid.org/0000-0001-8673-3034

\section{DISTRIBUTION PECULIARITIES OF BASIC ORE COMPONENTS IN GOSHGARCHAY PORPHYROUS COPPER DEPOSIT (LESSER CAUCASUS, AZERBAIJAN)}

Formulation of the problem. Large size and great reserves, as well as the possibility to apply rational methods of metals extraction predetermined the increasing interest to the copper-porphyry deposits. Today, they are the main raw material based on $\mathrm{Cu}$, Mo, accompanying metals all over the world. The value of these 
deposits lie in the fact that they are in located in geologically well-studied regions. However, their ores in basic and associated components have relatively small content of $\mathrm{Cu}, \mathrm{Mo}, \mathrm{Au}, \mathrm{Ag}, \mathrm{Bi}, \mathrm{Re}, \mathrm{Se}, \mathrm{Te}$, spreading in large area.

The purpose of the article. The main objective of the research is to study distribution peculiarities of basic ore components of Goshgarchay deposits, to detect geochemical features and behaviour of elements in the process of sedimentation by developing geochemical criteria of the search and the prognosis of hidden mineralization.

Methods. The author studied the distribution problem of basic ore components of copper-porphyry mineralization, carried out field investigations (field researches), documented and tested underground mine working and core samples of over seventy well bores.

When choosing the type of analysis, a special attention was paid to the sensitivity and exactness of the determination method. Analytical work was conducted according to the definition of chemical elements. The following types of analytical methods were used: chemical, atomic-absorption, spectral-chemical, etc. The analytical data were processed by the method of mathematical statistics.

Results. As follows from the analysis of the above-mentioned results, the elements flaccid for hydrothermal solutions $(\mathrm{Cr}, \mathrm{Ni}, \mathrm{V}, \mathrm{Co}, \mathrm{Mn}, \mathrm{Ti})$ keep their independence in all groups of rocks. Their grouping is probably associated with the process of crystallized differentiation of magma. The elements $\mathrm{Cu}, \mathrm{Pb}, \mathrm{Zn}, \mathrm{Ag}$ and partly Mo, don't have specific place. Their presence is likely associated with the degree of rocks susceptibility, hydrothermal interaction being the source of these elements. In various types of ores and mineral associations the definition of elemental impurities is different. Their amount increases the amount (quantity) of clarke and coefficient of concentration a thousand times. Three different mineral associations coexist in the ore body: 1-primary sulphide-chalcopyrite and bornite-chalcopyrite ore. 2-oxidized ore and zone of secondary enrichment. 3-primary sulphide ore, significantly enriched in copper.

Scientific novelty. Based on existing analytical data, the author studied distribution of basic ore and admixture components (gangue) and basic sulphide minerals. The concentration in series of elemental impurities were detailed in ore-bearing rocks of copper-porphyry deposits of Goshgarchay. The primary geochemical zonality was revealed in the distribution of basic ore-containing components in the ore body of copperporphyry deposits of Goshgarchay ore field.

Practical significance. The revealed peculiarities of the distribution of basic ore components in the ore body and host rocks (wallrock), the factors contributing to the accumulation of indicated elemental impurities can be used as geochemical criteria for the prognosis of copper-porphyry mineralization, supporting the effective directions of the research.

Keywords: Goshgarchay, copper-porphyry mineralization, structural-morphological, mineral composition, geochemical features, ore components, factoral analysis, pointed dependence, correlation relationship.

\section{References}

1. Mineral-raw resources of Azerbaijan (formation conditions, distribution patterns, scientific basis of prediction. (2005). Ed. By V.M. Babazadeh). Baku: Ozan Publ., 808. [in Russian]

2. Babazadeh V.M., Makhmudov A.I., Ramazanov V.G. (1990). Copper and molybdenum porphyry deposits: Baku: Azerneshr. 369. [in Russian]

3. Mansurov, M.I. (2014). Models of ore-magmatic systems of copper-porphyry in the deposits of Goshgarchay ore field (Lesser Caucasus, Azerbaijan). Journal of News of the Siberian department of the section of earth Sciences of the Russian Academy of Natural of Sciences. Geology, Exploration and Development of mineral deposits, 4(47), 29-42. [in Russian]

4. Popov, V.S. (1977). Geology and genesis of copper-molybdenum-porphyry deposits. Moscow: Science, 201. [in Russian]

5. Titley, S.R., Bean R.E. (1984). Porphyry copper deposits. Genesis of ore deposits. Moscow: Mir, 385. [in Russian]

6. Volkov, A.V., Savva, N.E., Sidirov, A.A. (2006). Regularities of distribution and conditions of formation of Cu-Auporphyry deposits in the North-East of Russia. Geology of ore deposits, 48 (6), 512-539. [in Russian]

7. Sillitoe, R.H. (2010). Porphyry Copper Systems, Society of Economic Geologists, Inc. Economic Geology, 105, 3-41.

8. Nikolaev, Yu. N., Baksheev, I.A., Prokofiev, V.Yu., Nagornaya, E.V., Marushchenko, L.I., Sidorina, Yu.N., Chitalin, A.F., Kalko, I.A. (2016). Au-Ag mineralization of porphyry-epithermal systems of the Baim zone (Western Chukotka, Russia). Geology of ore deposits, 58 (4), 319-345. [in Russian]

9. Geology of Azerbaijan, Tectonics, (2005). Baku: publishing house Nafta-Press, 565. [in Russian]

10. Abdullayev, R.N., Mustafayev. G.V., Mustafayev, M.A. (1988). Mesozoic magmatic formations of Lesser Caucasus and associated endogenous mineralization. Baku: Elm. 185. [in Russian]

11. Geology of Azerbaijan, Magmatism (2003). Baku: publishing house Nafta-Press, 505. [in Russian]

12. Mansurov, M.I. (2013). Geological-genetical model of Goshgarchay ore-magmatic system of Murovdag uplift. (Lesser Caucasus, Azerbaijan). Journal of News of ANAS. Earth Sciences, 4, 16-22. [in Russian] 
13. Mansurov, M.I., Safari, M.G., Kalandarov, B.G., Kerimov, V.M., Mammadova, A.G. (2018). Zonation of mineralization and metasomatites in porphyry copper deposits of the Goshgarchay ore-magmatic system (Lesser Caucasus, Azerbaijan). Bulletin of the Siberian Branch of the Earth Sciences Section of the Russian Academy of Natural Sciences. Geology, exploration and development of mineral deposits, 41 (1), 38-53. [in Russian]

14. Marushenko, L.I., Baksheev, I.A., Nagornaya, E.V., Chitalin, A.F., Nikolaev, Yu.N., Kalko, I.A., Prokofiev, V. Yu. (2015). Quartz-sericite metasomatites and mudllisites Au-Mo-Cu from the Peschanka deposit (Chukotka). Geology of ore deposits, 57(3), 239-252. [in Russian]

15.Imamverdiyev N.A., Baba-zadeh V.M., Mansurov M.I., Abdullayeva Sh. F.(2020). Rare-Earth elements in magmatic and metasomatic rocks of Murovdag ore area (Lesser Caucasus). Geochemistry Intenational, 2, 229-234. [in Russian]

16. Belonin, M.D., Golubeva, V.A., Skublov, G.T. (1982). Factor Analysis in Geology. Moscow, Nedra, 265. [in Russian]

17. Borovikov V.P. (2013). A popular introduction to modern data analysis in STATISTICA. Textbook for universities. [Text] / V.P. Borovikov. Moscow: Telecom hotline, 156. [in Russian]

18. Grabezhev A.I., Chashchukhina V.A. (1985). On the correlation between the elements of porphyry copper deposits // Geochemistry, 12, 1792-1794. [in Russian]

19. Baba-zade V.M. Ramazanov V.G., Abbasov N.A. (2015). Mineralogical and geochemical factors of gold content in ores of porphyry copper deposits of the Ordubad ore region. Bulletin of the Baku University. Series of natural sciences, 3, 122-129. [in Russian]

20. Naumov, N.B., Girnis, A.V., Dorofeeva, V.A., Kovalenker, V.A. (2016). Concentration of ore elements in magmatic melts and natural fluids according to the study of inclusions in minerals. Geology of ore deposits, 58(4), 367-384. [in Russian]

21. Geochemistry of migration processes of ore elements (1977). Under. ed. N.I. Khitarov. Moscow; Science, 270. [in Russian]

22. Karimli U. (2020). Stages of mineralization and localization factors of the Agyurt gold-copper-molybdenum deposit (Lesser Caucasus, Azerbaijan). Bulletin of Taras Shevchenko Kiev National University, 2, 96-101. http://doi.org/10.17721/1728-2713.89.13 [in Russian]

23. Ramazanov V.G. (1993). Porphyry copper formation of Azerbaijan. Baku: Elm, 45. [in Russian] 